\title{
ANALISIS PENERAPAN PERHITUNGAN BAGI HASIL BERDASARKAN EQUIVALENT RATE TERHADAP TABUNGAN MUDHARABAH PADA PT. BANK MEGA SYARIAH KANTOR CABANG PEMBANTU PEKANBARU
}

\author{
Susilawati \\ Sekolah Tinggi Ilmu Ekonomi (STIE) Syari’ah Bengkalis \\ Email: susilawatirasip92@gmail.com
}

\begin{abstract}
ABSTRAK
PT. Bank Mega Syariah Cabang Pekanbaru merupakan salah satu lembaga keuangaan syariah yang ada di kota Pekanbaru, yang berfungsi membantu masyarakat dalam meningkatkan perekonomian, dalam hal penelitian ini bertujuan untuk mengetahui bagaimana penerapan metode equivalent rate yang digunakan dalam menghitung bagi hasil pada akad mudharabah, pada PT. Bank Mega Syariah Cabang Pekanbaru dalam menghitung bagi hasil menggunakan akad mudharabah ialah metode equivalent rate yaitu dengan cara mengkonversi bagi hasil untuk seluruh nasabah pada masing-masing produk DPK kedalam bentuk persentase yang dihitung dari total saldo rata-rata tiap jenis produk dan menghitung besar pendapatan yang akan di bagi hasilkan untuk masing-masing jenis produk. Maka kemungkinan yang akan terjadi ialah tingkat bagi hasil yang diterima oleh oleh pemilik dana akan mengalami perubahan setiap bulannya tergantung besar pendapatan yang diperoleh oleh bank atas hasil penyaluran. Kondisi ini akan mempengaruhi para pemilik dana untuk melakukan investasi kepada bank syariah yang nyatanya justru memberikan hasil yang benar-benar dari pendapatan yang diperoleh oleh bank secara optimal sehingga layak dan mampu memberikan keuntungan yang maksimal bagi pemilik dana. Dari penelitian yang penulis lakukan tersebut maka dapat diketahui bahwa metode equivalent rate tabungan mudharabah pada PT. Bank Mega Syariah Cabang Pekanbaru, telah sesuai dengan Fatwa MUI tentang tabungan mudharabah, dimana contoh kasus yang penulis ilustrasikan dengan metode equivalent rate baik bank maupun nasabah sama-sama mendapatkan keuntungan sesuai perolehan pendapatan dengan nisbah yang telah disepakati pada perjanjian awal.
\end{abstract}

Kata kunci: Bagi Hasil, Equivalent Rate, Tabungan, Mudharabah

\section{PENDAHULUAN}

Perkembangan Perbankan Syari'ah pada era reformasi di tandai dengan disetujuinya undang-undang No. 10 Tahun 1998 Tentang perubahan UndangUndang No. 7 Tahun 1992 Tentang Perbankan. Dalam Undang-Undang tersebut diatur dengan rinci Landasan Hukum serta jenis-jenis usaha yang dapat dioprasikan dan di implementasikan oleh Bank Syari,ah. Undang-undang tersebut juga memberikan arahan bank-bank konvensional untuk membuka cabang Syari'ah atau bahkan mengkonversi diri secara total menjadi Bank Syari'ah (Antonio 2001). 
Perbankan Syari'ah atau Perbankan Islam (Al-Masharafiyah Al-Islam) adalah suatu sistem perbankan yang pelaksananya berdasarkan prinsip-prinsip Syari'ah Islam, dengan mengacu kepada Al-Qur'an dan sunah sebagai landasan dasar hukum dan oprasional. Bank Syari'ah beroperasi dengan tidak mengandalkan pada bunga (riba). Fungsi utama dari perbankan adalah menerima simpanan uang, meminjamkan uang, dan melayani jasa pengiriman uang.

Dalam menjalankan prinsip syari'ahnya, Bank Mega Syari'ah juga harus menjunjung nilai-nilai keadilan, amanah, kemitraan transparansi dan saling menguntungkan baik bagi bank maupun nasabah yang melakukan aktivitas muamalah. Oleh karena itu, produk layanan perbankan harus disediakan untuk mampu memberikan nilai tambah dalam meningkatkan kesejahteraan ekonomi masyarakat yang berlandaskan pada nilai-nilai Islam.

Salah satu produk dan layanan Bank Mega Syariah adalah produk Tabungan Mudharabah yang melayani nasabah dalam meneriama simpanan uang yang dapat membantu masyarakat dalam menyimpan uang/berinvestasi dalam bentuk penanaman dana dari pemilik dana (Shahibul Maal) kepada pengelola dana bank sebagai (Mudharib) untuk melakukan kegiatan usaha tertentu yang sesuai Syari'ah, dengan pembagian hasil usaha antara kedua belah pihak berdasarkan nisbah yang telah disepakati sebelumnya. Sehingga semua atau hampir semua Lembaga Keuangan Syari'ah menjadikannya sebagai produk investasi dalam tabungan atas dasar akad Mudarabah yang telah disepakati. (Antonio 2001, 90)

Tabungan Mudarabah salah satu bentuk dari investasi atas suatu jenis perkongsian, dimana pihak pertama (Shahib Al'mal) menyediakan dana, dan pihak kedua (Mudharib) bertanggung jawab atas pengelolaan usaha. Hasil usaha dibagikan sesuai dengan nisbah (porsi bagi hasil) yang telah disepakati bersama secara awal. Bagi hasil dalam Bank Syari'ah menggunakan istilah nisbah bagi hasil, yaitu proporsi bagi hasil antara nasabah dan bank syariah. Nisbah adalah rukun yang khas dalam akad mudharabah, yang tidak ada dalam akad jual beli. Nisbah ini mencerminkan imbalan yang berhak diterima oleh kedua pihak yang bermudharabah. Mudharib mendapatkan imbalan atas kerjanya, sedangkan shahib al-maal mendapat imbalan atas penyertaan modalnya. Nisbah keuntungan inilah yang akan mencegah terjadinya perselisihan antara kedua belah pihak mengenai cara pembagian keuntungan (Yahya)

Dalam perhitungan bagi hasil ada beberapa metode yang digunakan salah satunya adalah metode Equivalent Rate yaitu menghitung bagi hasil untuk nasabah dengan cara mengkonversi bagi hasil untuk seluruh nasabah pada masing-masing produk DPK kedalam bentuk persentase (Equivalent Rate). Nisbah tabungan mudharabah yang bersifat nominal selanjutnya di konversikan menjadi Equivalent Rate. Seluruh pendapatan investasi yang akan di bagikan kepada nasabah yaitu DPK (Dana Pihak Ketiga) dari total return (keuntungan) yang di peroleh untuk dihitung besarnya pendapatan yang akan di bagi hasilkan untuk masing-masing jenis produk. Khusus produk DPK dalam bentuk tabungan dengan akad Mudharabah yang masih merupakan pendapatan yang menjadi milik bank dan nasabah. (Karim 2004, 405) 


\section{TINJAUAN PUSTAKA}

\section{Konsep Mudharabah}

Mudharabah berasal dari kata dharb, yang berarti memukul atau berjalan. Pengertian memukul atau berjalan ini lebih tepatnya adalah proses seseorang memukulkan kakinya dalam menjalankan usahanya. Adapaun pengertian teknisnya mudharabah adalah akad kerjasama usaha antara dua pihak dimana pihak pertama (shahibul maal) menyediakan seluruh $100 \%$ modal, sedangkan pihak lain menjadi pengelola (Sumiyanto 2005, 1).

Bentuk kontrak antara dua pihak dimana satu pihak berperan sebagai pemilik modal dan mempercayakan jumlah modalnya untuk dikelola oleh pihak kedua yakni si pelaksana usaha, dengan tujuan untuk mendapatkan untung (Sumiyanto 2005, 2).

Firman Allah dalam Al-Qur,an Surah Al-Maidah ayat 1:

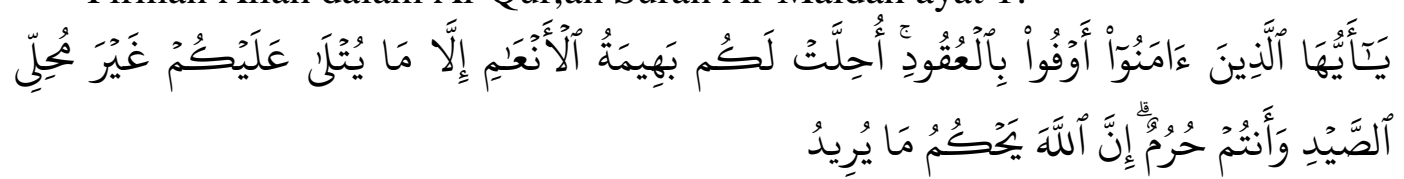

Artinya: Hai orang-orang yang beriman, penuhilah aqad-aqad....

Hadist Nabi Riwayat Thabrani :

"Abbas bin Abdul Muthalib jika menyerahkan harta sebagai mudharabah, ia mensyaratkan kepada mudharibnya agar tidak mengarungi lautan dan tidak menuruni lembah, serta tidak membeli hewan ternak, jika persyaratannya itu dilanggar ia (mudharib) harus menanggung resikonya, ketika persyaratan yang ditetapkan Abbas itu dengar Rasulullah beliau membenarkanya".

Aplikasi prinsip ini adalah bahwa deposan atau penyimpan bertindak sebagai shahibul maal dan bank sebagai mudharib. Dana ini digunakan bank untuk melakukan pembiayaan akad jual beli maupun syirkah. Jika terjadi kerugian maka bank bertanggungjawab atas kerugian yang terjadi. Rukun mudharabah yaitu ada pemilik dana, ada usaha yang akan dibagihasilkan, ada nisbah, dan ada ijab qabul. Aplikasi prinsip mudharabah dalam produk penghimpunan dana yaitu tabungan berjangka dan deposito berjangkan. Sedangkan berdasarkan kewenangan penggunaan dana, prinsip mudharabah dibagi menjadi (Muhammad dan Suwiknyo 2009, 15):

1. Mudharabah Mutlaqah

Penerapan mudharabah mutlaqah dapat berupa tabungan dan deposito sehingga terdpat dua jenis penghimpunan dana yaitu : tabungan mudharabah dan deposito mudharabah. Berdasarkan prinsip ini tidak ada pembatasan bagi bank dalam menggunakan dana yang di himpun.

Kententuan umum diantaranya:

a. Bank wajib memberitahukan kepada pemilik dana mengenai nisabah dan tata cara pemberitahuan keuntungan dan atau pembagaian dana yang dicantumkan dalam akad.

b. Untuk tabungan mudharabah, bank dapat memberikan buku tabungan sebagai bukti penyimpanan. Untuk deposito mudharabah, bank wajib memberikan sertifikat atau tanda penyimpanan deposito kepada deposan. 
c. Tabungan mudharabah dapat diambil setiap saat oleh penabungan sesuatu dengan perjanjian yang disepakati, namun tidak diperkenankan mengalami saldo negativ.

d. Deposito mudharabah hanya dapat dicairkan sesuai dengan jangka waktu yang telah disepakati. Deposito yang diperpanjang, setelah jatuh tempo akan diperlakukan sama seperti deposito baru, tetapi bila pada akad sudah dicantumkan perpanjangan otomatis maka tidak perlu dibuat akad baru.

e. Ketentuan-ketentuan yang lain yang berkaitan dengan deposito atau tabungan tetap berlaku sepanjang tidak bertentangan dengan syariah:

2. Mudharabah Muqayyadah

Akad Mudharabah Muqayyadah terbagi menjadi 2 yaitu:

a. Mudharabah Muqayyadah on Balance Sheet

Jenis Mudrabah ini merupakan simpanan khusus (restricted investment) dimana pemilik dana dapat menetapkan syarat tertentu yang harus dipatuhi oleh bank. Karakteristik jenis simpanan ini diantaranya :

a) Pemilik dana wajib menetapkan syarat tertentu yang harus diikuti bank.

b) Bank wajib memberitahukan kepada pemilik dana mengenai nisbah dan tata cara pemberitahuan keuntungan.

c) Sebagai tanda bukti simpanan, bank menerbitkan bukti simpanan khusus. Bank wajib memisahkan dana dari rekening lain.

d) Untuk deposito mudharabah, bank wajib memberikan sertifikat atau tanda penyimpanan deposito kepada deposan.

b. Mudaharabah Muqayyadah off Balance Sheet

Jenis Mudahrabah ini merupakan penyaluran dana mudharabah langsung kepada pelaksana usahanya, dimana bank bertindak sebagai perantara yang memperteumkan antara pemilik dana dengan pelaksana usaha. Pemilik dana dapat menetapkan syarat-syarat tertentu yang harus dipatuhi oleh bank dalam mencari kegiatan usaha yang akan dibiayai dan pelaksana usahanya. Karateristiknya:

a) Sebagai tanda bukti simpanan, bank menerbitkan bukti simpanan khusus.

b) Bank wajib memisahkan dana dari rekening lainnya.

c) Rekening khusus dicatat pada pos tersendiri dalam rekening adaministrative.

d) Dana simpanan khusus harus disalurkan secara langsung kepada pihak yang diamanatkan oleh pemilik dana.

e) Bank menerima komisi atas jasa mempertemukan kedua pihak.

f) Antara pemilik dana dan pelaksana usaha berlaku nisbah bagi hasil.

Prinsip mudharabah dalam produk Bank Syariah dapat dikembangkan untuk jenis produk giro,tabungan maupun deposito.

3. Mudharabah Musytarakah

Mudharabah Musytarakah adalah Mudharabah dimana pengelola dana menyertakan modal atau dananya dalam kerja sama investasi. Di awal kerjasama, akad yang disepakati adalah akad mudharabah dengan modal $100 \%$ dari pemilik dana, setelah berjalannya operasi usaha dengan pertimbangan tertentu dan kesepakatan dengan pemilik dana, pengelola dana ikut menanamkan modalnya dalam usaha tersebut jenis mudharabah seperti ini 
disebut mudharabah musytarakahmerupakan perpaduan antara akad mudharabah dan akad musytarakah. (Nurhayati dan Wasilah 2009, 123)

Rukun dan Syarat Bagi Hasil Mudharabah 35):

Adapun rukun dan syarat bagi hasil mudharabah antara lain (Ascarya 2007,

a. Rukun dari akad Mudharabah yang harus dipenuhi dalam transaksi ada beberapa, yaitu:

a) Pelaku akad, yaitu para mitra usaha (pemilik modal maupun pelaksanaan usaha).

b) Objek akad, yaitu modal (mal),kerja (dharabah), dan keuntungan (ribh).

c) Shighah, yaitu Ijab dan Qabul.

d) Nisbah keuntungan

b. Beberapa syarat pokok mudharabah yang harus di terpenuhi yaitu Syarat akad, karena Mudharabah merupakan hubungan yang dibentuk oleh para mitra melalui kontrak/akad yang disepakati bersama, adapun syarat akad yaitu :

a) Syarat berlaku akad (In'iqod)

b) Syarat sahnya akad (Shihah)

c) Syarat tererealisasikannya akad (Nafadz)

d) Syarat Lazim yang harus dipenuhi.

Tabungan Mudharabah adalah tabungan yang dijalankan berdasarkan akah mudharabah. Dari hasil pengelolaan dana mudhrabah,bank syariah akan membagi hasilkan kepada pihak dana sesuai dengan nisbah yang telah disepakati dan dituangkan dalam akad pembukaan rekening. Dalam pengelolaan dana tersebut, bank tikda bertanggungjawab terhadap kerugian yang bukan disebabkan dari kelalaianya. Namun, apabila yang terjadi adalah mis-managemen (salah urus), bank bertanggung jawab penuh terhadap kerugian tersebut. (Ascarya 2007, 35)

Fatwa MUI tentang Tabungan Mudharabah

Tabungan ada dua jenis:

a. Tabungan yang tidak dibenarkan secara syari'ah, yaitu tabungan yang berdasarkan perhitungan bunga.

b. Tabungan yang dibenarkan, yaitu tabungan yang berdasarkan prinsip Mudharabah dan Wadi'ah.

Tabungan berdasarkan Mudharabah:

a. Dalam transaksi ini nasabah bertindak sebagai shahibul mal atau pemilik dana, dan bank bertindak sebagai mudharib atau pengelola dana.

b. Dalam kapasitasnya sebagai mudharib, bank dapat melakukan berbagai macam usaha yang tidak bertentangan dengan prinsip syari'ah dan mengembangkannya, termasuk di dalamnya mudharabah dengan pihak lain (Ascarya 2007, 38).

c. Modal harus dinyatakan dengan jumlahnya, dalam bentuk tunai dan bukan piutang.

d. Pembagian keuntungan harus dinyatakan dalam bentuk nisbah dan dituangkan dalam akad pembukaan rekening. 
e. Bank sebagai mudharib menutup biaya operasional tabungan dengan menggunakan nisbah keuntungan yang menjadi haknya.

f. Bank tidak diperkenankan mengurangi nisbah keuntungan nasabah tanpa persetujuan yang bersangkutan.

\section{Konsep Bagi Hasil}

Bagi hasil adalah penghasilan bersih (laba) sering sekali digunakan sebagai ukuran kinerja atau sebagian dasar bagi ukuran yang lain seperti imbalan hasil atau laba persaham (IAI 2007). Jadi bisa diambil kesimpulan bahwa bagi hasil adalah pendapatan yang diperoleh dari investasi atau reproduksi antara pemilik dana dengan pengelola dana dengan nisbah yang telah disepakati, biasanya perjanjian atau kontrak bagi hasil ini terjadi diawal akad, hal ini harus bersifat transparan antara pemilik dana dengan pengelola dana.

Fatwa Dewan Syariah Nasional Nomor 14/DSN-MUI/IX/2000 Tentang Sistem Distribusi Hasil Usaha Dalam Lembaga Keuangan Syariah. ${ }^{1}$

a. Pada prinsipnya, LKS boleh menggunakan sistem Accrual Basis maupun Cash Basis dalam administrasi keuangan.

b. Dilihat dari segi kemaslahatan (al-ashlah), dalam pencatatan sebaiknya digunakan sistem Accrual Basis; akan tetapi, dalam distribusi hasil usaha hendaknya ditentukan atas dasar penerimaan yang benar-benar terjadi (Cash Basis).

c. Penetapan sistem yang dipilih harus disepakati dalam akad.

Langkah-langkah distribusi hasil usaha dapat dijelaskan sebagai berikut:

a. Pendapatan yang akan didistribusi atau dibagi dengan pemilik dana (pemodal / investor) adalah pendapatan yang diperoleh dari pengelolaan dana yang disebut dengan "pendapatan usaha utama", yaitu pendapatan dari jual beli (keuntungan murabahah, keuntungan salam, dan keuntungan istishna), pendapatan ujroh (pendapatan neto Ijarah, Ijarah Muntahiya Bittamlik, Multijasa) dan pendapatan bagi hasil (pendapatan bagi hasil mudharabah dan musyarkah) dan pendapatan pengelolaan dana lainnya (pendapatan sertifikat investasi mudharabah antar bank syariah / SIMA, pendapatan bonus sertifikat Wadiah Bank Indonesia).

b. Pendapatan Usaha Utama sebagaimana dalam butir 1 diatas, harus dapat dipisahkan :

a) Pendapatan Akrual

Pendapatan dari hasil pengelolaan usaha utama, yang dilakukan hanya dalam pengakuan saja, tidak diikuti dengan aliran kas (belum diterima). Pengakuan pendapatan ini dilakukan dengan tujuan untuk memberikan gambaran yang lengkap kepada pengguna laporan keuntungan bank syariah.Pendapatan akrual hanya untuk kepentingan laporan keuangan dan tidak boleh dibagikan kepada pihak ketiga / pemilik dana.

b) Pendapatan nyata-nyata diterima (cash basis)

Pendapatan yang nyata-nyata diterima atau cash basis merupakan pendapatan pengelolaan usaha utama bank syariah yang nyata-nyata diterima, baik akibat dari pendapatan yang diterima saat ini atau akibat

${ }^{1}$ Dewan Syari'ah Nasional, Fatwa Dewan Syari'ah Nasional Nomor 14/DSN-MUI/IX/ 2000 Tentang Sistem Distribusi Hasil Usaha dalam LKS, (Jakarta: DSN, 2000), 
dari aliran kas dari pendapatan yang pengakuannya dilakukan sebelumnya dan kasnya baru diterima saat ini.

Sesuai ketentuan Fatwa Dewan Syariah Nasional nomor 14/DSNMUI/IX/2000 Tentang Sistem Distribusi Hasil Usaha Dalam Lembaga Keuangan diatur bahwa: ${ }^{2}$

Bank Syariah boleh menggunakan sistem Accrual Basis maupun Cash Basis dalam administrasi keuangan. Dilihat dari segi kemaslahatan (alashlah), dalam pencatatan sebaiknya digunakan sistem Accrual Basis; akan tetapi, dalam distribusi hasil usaha hendaknya ditentukan atas dasar penerimaan yang benar-benar terjadi (Cash Basis).

Jadi pendapatan yang diperkenankan untuk dibagi dengan pemilik dana adalah pendapatan dari pengelolaan usaha utama yang nyata-nyata diterima.

c. Langkah berikutnya dari pendapatan yang nyata-nyata diterima (cash basis) dipisahkan pendapatan menjadi pendapatan yang sumber dananya dari pihak ketiga dan sisanya merupakan pendapatan cash basis dari sumber dana lainnya. Pemisahan tersebut dilakukan karena pendapatan dari pemilik dana (khususnya sumber dana mudharabah) sangat tergantung pada pendapatan bank syariah. Oleh karena itu dalam usaha bank syariah (jual beli, Ijarah dan bagi hasil) hendaknya dibiayai dari modal pemodal eksternal dulu. Perlu diingat bahwa sebagian dari pendapatan usaha utama bank syariah merupakan haknya pemodal eksternal (dana pihak ketiga).

d. Sesuai prisipnya pemodal eksternal (dana pihak ketiga) dibedakan sumber dana dengan prinsip wadiah (giro wadiah dan tabungan wadiah) dan sumber dana yang mempergunakan prinsip mudharabah (tabungan mudharabah dan deposito mudharabah). Pemisahan ini dilakukan karena pada prinsipnya hanya pendapatan sumber dana yang mempergunakan prinsip mudharabah saja yang akan dibagi antara pemilik dana (shahibil mal) dengan pengelola dana (mudharib). Sedangkan pendapatan dari sumber dana yang mempergunakan prinsip wadiah (wadiah yad dhamanah) merupakan pendapatan bank syariah seluruhnya. Sumber dana dengan prinsip wadiah perlu diketahui berapa pendapatannya dapat dipergunakan sebagai pertimbangan dalam memberikan bonus kepada pemodal (penitip). Jika bank syariah memberikan bonus diharapkan tidak melebihi dari pendapatan wadiah yang diperoleh, supaya tidak ada pendapatan lain yang dialokasikan untuk bonus yang mengakibatnya laba rugi bank syariah berkurang.

e. Pada prinsipnya hanya pendapatan sumber dana dengan prinsip mudharabah yang memperolah bagi hasil, atau sumber dana mudharabah yang merupakan komponen bagi hasil. Tetapi untuk kepentingan analisa dan kepentingan lain seperti laporan Bank Indonesia, sumber dana mudharabah dipisahkan sesuai produk masing-masing misalnya tabungan mudharabah, deposito mudharabah jangka waktu satu bulan, deposito mudharabah jangka waktu 3 bulan dan sebagainya (selanjutnya disebut dengan kelompok dana). Pemisahan seperti ini dilakukan untuk mengetahui return masing-masing produk dan perhitungan bagi hasil individu.

${ }^{2}$ Dewan Syari'ah Nasional, Fatwa Dewan Syari'ah Nasional Nomor 14/DSN-MUI/IX/2000 Tentang Sistem Distribusi Hasil Usaha dalam LKS, ( Jakarta: DSN, 2000), 
f. Pendapatan kelompok dana merupakan pendapatan milik bersama antara pemilik modal (shahibul maal) dengan pengelola (mudharib). Oleh karena itu perlu dipisahkan pendapatan milik sekelompok dana (misalnya sekelompok penabung tabungan mudharabah). Pendapatan sekelompok pemodal / dana ini tidak diperkenankan untuk dikurangi, karena ini adalah hak orang lain. Pendapatan sekelompok dana ini merupakan pendapatan milik semua pemodal individu yang tergabung dalam kelompok dana tersebut.

g. Dari pendapatan sekelompok dana tersebut dibagikan kepada masing-masing pemodal individu. Untuk keperluan perhitungan pada masing-masing pemodal individu dapat dituangkan dalam bentuk prosentase return (kesetaraan return) atau hasil investasi setiap seribu rupiah. Prosentase return atau hasil investasi per seribu ini dari bulan ke bulan berubah-ubah karena dipengaruhi pendapatan yang diterima oleh bank syariah yang berubah-ubah. Jadi bagi hasil atau pendapatan individu ini sangat dipengaruhi oleh pendapatan sekelompok dana, pendapatan sekelompok dana dipengaruhi oleh pendapatan yang dibagi, pendapatan yang dibagi dipengaruhi oleh pembayaran angsuran, pembayaran angsuran dipengaruhi oleh kualitas pengelolaan dana dst. Hal inilah kenapa prosentase return bagi hasil tidak diharamkan.

\section{Bagi Hasil berdasarkan Metode Equivalent Rate}

Metode lain dalam menghitung Bagi Hasil untuk masing-masing nasabah adalah dengan menggunakan Metode "Equivalent Rate". Adapun proses perhitungan Bagi Hasil untuk masing-masing nasabah dengan metode "Equivalent Rate"adalah sebagai berikut (Karim 2004, 405):

1. Hitung "PAD per produk"

PAD per Produk adalah besarnya penadapatan yang akan dibagi hasilkan untuk masing-masing jenis produk DPK. Untuk menghitung PAD per Produk, digunakan persamaan sebagai berikut :

Saldo rata-rata tiap jenis produk DPK

$$
\begin{aligned}
& \text { PAD per Produk }==\times \text { PAD } \\
& \text { Total Saldo rata-rata DPK }
\end{aligned}
$$

2. Hitung "Bagi Hasil untuk Seluruh Nasabah Per Produk"

Pada butir 1 telah dihitung PAD per Produk DPK. Khusus untuk produk DPK dengan akad Mudharabah, PAD tersebut masih merupakan pendapatan yang menjadi milik bank dan nasabah. Selanjutnya, menghitung PAD yang merupakan milik (menjadi porsi) nasabah DPK untuk jenis setiap produk, yang selanjutnya disebut : Bagi Hasil untuk Seluruh Nasabah Per Produk adalah bagi hasil yang akan dibagikan ke Seluruh Nasabah DPK sesuai jenis produk DPK. Perhitungan Bagi Hasil untuk Seluruh Nasabah Per Produk menggunakan persamaan berikut:

\section{Bagi Hasil}

Seluruh Nasabah $=$ PAD Per Produk x Nisbah/100

Per Produk

3. Hitung "Equivalent Rate Setiap Produk"

Yang dimaksud dengan Metode Equivalent Rate adalah menghitung Bagi Hasil untuk nasabah dengan cara mengonversi bagi hasil untuk seluruh 
nasabah pada masing-masing produk DPK ke dalam bentuk persentase (equivalent rate). Persamaan yang digunakan adalah sebagai berikut :

$$
\begin{array}{ll}
\text { Equivalent Rate } & \begin{array}{c}
\text { Bagi hasil untuk seluruh } \\
\text { Nasabah Per Produk }
\end{array} \\
\text { Setiap Produk }= & \text { Total Saldo rata-rata per produk }
\end{array}
$$

4. Hitung "Bagi Hasil Per Nasabah DPK"

Perhitungan Bagi Hasil Per Nasabah DPK dilakukan dengan mengalikan jumlah dana setiap Nasabah DPK dengan eqivalent rate yang telah dihitung pada butir 3 diatas.

\section{METODOLOGI PENELITIAN}

Yang menjadi objek penelitian ini adalah Analisis Penerapan Perhitungan Bagi Hasil Berdasarkan Equivalent Rate terhadap Tabungan Mudharabah pada PT. Bank Mega Syariah Kantor Cabang Pembantu Pekanbaru.

Sedangkan sumber data dari penelitian ini adalah data primer data skunder. Data primer yaitu data yang diperoleh langsung dari subjek penelitian. Data skunder yaitu data yang diperoleh dari perusahaan dalam bentuk yang telah jadi dan disusun oleh perusahaan. Dengan menggunakan alat pengukuran atau alat pengambilan data langsung pada subjek sebagai sumber informasi yang dicari.

Karena penelitian ini menggunakan data kualitatif, maka instrumen yang digunakan untuk mengumpulkan data adalah observasi, interview/wawancara, dokumentasi, dan kepustakaan.

\section{Tehnik Analisis Data}

Dalam menganalisis data, penulis mengunakan metode deskriptif dan komparatif. Dimana metode deskriptif yaitu menelaah data-data yang diperoleh dari PT BMS, dan menyajikan datanya, kemudian ditambahi dengan teori-teori yang mendukung.

Sedangkan metode komparatif digunakan untuk membandingkan kesesuaian antara teori dan praktek, yaitu pelaksanaan tabungan mudharabah di BMS KCP Pekanbaru dengan Fatwa DSN. Dari hasil perbandingan tersebut diberikan argumentasi yang selanjutnya akan digunakan sebagai dasar untuk penyajian kesimpulan dan saran.

\section{HASIL DAN PEMBAHASAN PENELITIAN}

\section{PT. Bank Mega Syariah Kantor Cabang Pembantu Pekanbaru Menerapakan Perhitungan Equivalent Rate Terhadap Penentuan Bagi Hasil Tabungan Mudharabah (Investasya iB)}

Pada dasarnya di lapangan, kegiatan utama bank syariah adalah menghimpun dana dalam bentuk tabungaan dan menyalurkan dana dalam bentuk modal kerja dan pembiayaan dari masyarakat, seperti dalam hal pemberian pembiayaan untuk debitur serta penempatan dana dibank atau investasi lain yang dapat menghasilkan pendapatan untuk di bagi hasilkan kepada nasabah.

Sebagaimana kita ketahui, bahwa bank mega syariah memiliki produk pendanaan tabungan mudharabah (investasya iB) adalah tabungan berkonsep 
mudharabah, yang memberikan nisabah yang lebih tinggi untuk dana investasi yang lebih besar. Produk ini dapat digunakan untuk nasabah perorangan ataupun nasabah perusahaan.Kemudahan dalam menyimpan/ menginvestasikan dana dengan bagi hasil yang tinggi yaitu bagi hasil yang kompetitif. ${ }^{3}$

Berdasarkan dari hasil wawancara penelitian yang telah penulis lakukan, pihak bank menjurnal tidak secara manual tetapi sudah menggunakan otomatis by sistem yang mana akan menjurnal transaksi sesuai contoh kasus sebagai berikut.

Bapak Amir, sebagai nasabah Bank Mega Syariah sejak 2013 mempunyai Tabungan Mudharabah dengan saldo rata-rata bulan Maret, Juni dan Bulan September 2014 sebesar Rp.5.000.000

\section{Tabel 1}

Distribusi Bagi Hasil

Tanggal 31 Maret 2014

(Jutaan Rupiah)

\begin{tabular}{cccccc} 
& & & \multicolumn{3}{c}{ Porsi Nasabah } \\
\cline { 3 - 5 } $\begin{array}{c}\text { Jenis } \\
\text { Penghimpunan }\end{array}$ & $\begin{array}{c}\text { Saldo rata- } \\
\text { rata }\end{array}$ & $\begin{array}{c}\text { Pendapatan } \\
\text { yang harus } \\
\text { dibagikan }\end{array}$ & Nisbah & $\begin{array}{c}\text { Jumlah } \\
\text { bonus dan } \\
\text { bagi hasil }\end{array}$ & $\begin{array}{c}\text { Rate Of } \\
\text { Return } \\
\text { (Equivalent } \\
\text { Rate) }\end{array}$ \\
& A & B & C & D & E
\end{tabular}

1. Giro wadiah

a. Bank

b. Non Bank

351.855

$5.276 \quad 20,07 \%$

1.376

$4,69 \%$

2. Tabungan Wadiah
a. Bank
b. Non Bank
800.718
$12.007 \quad 15,87 \%$
$1.906 \quad 2,86 \%$

3. Tabungan

Mudharabah

$\begin{array}{lrrrrr}\text { a. Bank } & 6.290 & 94 & 31,51 \% & 30 & 5,67 \% \\ \text { b. Non Bank } & 420.230 & 6.301 & 31,51 \% & 1.985 & 5,67 \%\end{array}$

4. Deposito

Mudharabah

\begin{tabular}{|c|c|c|c|c|c|}
\hline \multicolumn{6}{|l|}{ a. Bank } \\
\hline 1 bulan & 11.387 & 171 & $27,42 \%$ & 47 & $4,90 \%$ \\
\hline 3 bulan & - & - & - & - & - \\
\hline 6 bulan & - & - & - & - & - \\
\hline 12 bulan & - & - & - & - & - \\
\hline \multicolumn{6}{|c|}{ b. Non Bank } \\
\hline 1 bulan & 3.551 .526 & 53.255 & $27,24 \%$ & 14.507 & $4,90 \%$ \\
\hline 3 bulan & 1.489 .593 & 22.336 & $27,14 \%$ & 6.062 & $4,88 \%$ \\
\hline 6 bulan & 134.083 & 2.011 & $25,96 \%$ & 522 & $4,67 \%$ \\
\hline 12 bulan & 144.770 & 2.171 & $25,96 \%$ & 564 & $4,67 \%$ \\
\hline Total & 6.910 .452 & 103.622 & & & \\
\hline
\end{tabular}

Adapun perhitungan bagi hasil berdasarkan equivalent rate yang diterapkan oleh Bank Mega Syariah menggunakan Otomatis By Sistem Sama dengan cara manual yang berlaku yaitu sebagai berikut:

\footnotetext{
${ }^{3}$ Wawancara Karyawan BMS Cabang Pekanbaru, Ica, Bagian Coustemer Servis.
} 
1. Hitung "PAD per produk"

Saldo rata-rata tiap jenis produk DPK

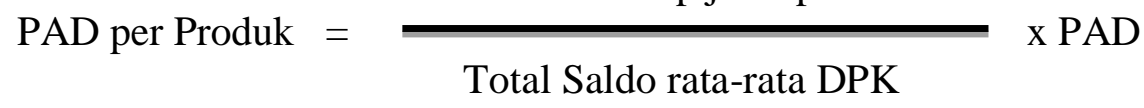

$$
\begin{aligned}
& =\frac{\text { Rp. } 420.230 .000 .000}{\text { Rp. } 6.910 .452 .000 .000} \times \text { Rp. } 103.622 .000 .000 \\
& =\quad \text { Rp. } 6.301 .000 .000
\end{aligned}
$$

2. Hitung "Bagi Hasil untuk Seluruh Nasabah Per Produk"

Bagi Hasil

Seluruh Nasabah $\quad=$ PAD Per Produk $\mathrm{x}$ Nisbah $/ 100$

Per Produk

$$
\begin{aligned}
& =\text { Rp.6.301.000.000x31,51/100 } \\
= & \text { Rp. } 1.985 .445 .100
\end{aligned}
$$

3. Hitung "Equivalent Rate Setiap Produk"

$$
\begin{aligned}
& \text { Equivalent Rate } \\
& \text { Setiap Produk }=
\end{aligned}
$$

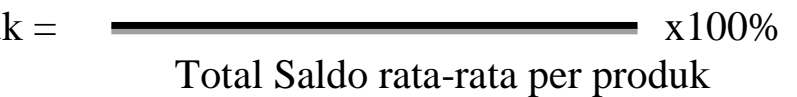

Rp. 1.985.445.100

$$
\begin{aligned}
& =\quad \frac{\text { Rp. } 420.230 .000 .000}{} \times 100 \% \\
& =\quad \text { Rp. } 5,67 \%
\end{aligned}
$$

4. Hitung "Bagi Hasil Per Nasabah DPK"

Perhitungan Bagi Hasil Per Nasabah DPK dilakukan dengan mengalikan jumlah dana setiap Nasabah DPK dengan equivalent rate yang telah dihitung pada butir $\mathrm{c}$ diatas.

Bagi hasil yang diterima Bapak Amir atas Tabungan Mudharabah pada bulan Maret adalah:

Bagi Hasil = Saldo Rata-rata bapak Amir $\times$ Equivalent rate (\%)

Bapak Amir

$$
\begin{aligned}
& =\text { Rp. } 5.000 .000 \times(5.67 \% /(365 / 31) \\
& =\text { Rp. } 5.000 .000 \times 5,67 \% /(11,7741935483) \\
& =\text { Rp. } 5.000 .000 \times 0,4815 \% \\
& =\text { Rp. } 24.075
\end{aligned}
$$

Jurnal Pada Saat Penerimaan Bagi Hasil Mudharabah untuk Pak Amir untuk Bulan Maret 2014 adalah:

Hak Pihak Ketiga Atas Bagi Hasil Rp. 24.075

Tabungan Mudharabah

Rp. 24.075 


\section{Tabel 2}

Distribusi Bagi Hasil

Tanggal 30 Juni 2014

(Jutaan Rupiah)

\begin{tabular}{|c|c|c|c|c|c|}
\hline \multirow{3}{*}{ Jenis Penghimpunan } & \multirow[b]{2}{*}{$\begin{array}{l}\text { Saldo rata- } \\
\text { rata }\end{array}$} & \multirow[b]{2}{*}{$\begin{array}{c}\text { Pendapatan } \\
\text { yang harus } \\
\text { dibagikan }\end{array}$} & \multicolumn{3}{|c|}{ Porsi Nasabah } \\
\hline & & & Nisbah & $\begin{array}{c}\text { Jumlah } \\
\text { bonus dan } \\
\text { bagi hasil }\end{array}$ & $\begin{array}{c}\text { Indikasi } \\
\text { Rate Of } \\
\text { Return } \\
\text { (Equivalent } \\
\text { Rate) }\end{array}$ \\
\hline & A & B & & D & \\
\hline
\end{tabular}

1. Giro wadiah

a. Bank

b. Non Bank

268.536

3. 958

2. Tabungan Wadiah
a. Bank
b. Non Bank
623.773
9.193

3. Tabungan Mudharabah
a. Bank
4.203
62
$11,74 \% \quad 7$
$2.08 \%$
b. Non Bank
508.312
7.492
$11.74 \% \quad 880$
$2,08 \%$

4. Deposito Mudharabah

a. Bank

1 bulan

71.426

1.053

$27,47 \% \quad 289$

$4,86 \%$

3 bulan

6 bulan

12 bulan

b. Non Bank

1 bulan

3.435 .223

50.629

$27,47 \% \quad 13.908 \quad 4,86 \%$

3 bulan

1.499 .612

22.102

$27,36 \% \quad 6.047$

$4,84 \%$

6 bulan

170.089

2.507

$26,17 \% \quad 656$

$4,63 \%$

12 bulan

82.456

1.215

$26,17 \% \quad 318$

$4,63 \%$

Total

6.663631

98.211

22.105

Perhitungan bagi hasil untuk bapak amir pada bulan Juni 2014 adalah:

1. Hitung "PAD per produk"

Saldo rata-rata tiap jenis produk DPK

$\mathrm{PAD}$ per Produk =

Total Saldo rata-rata DPK

$$
\begin{aligned}
& =\quad \frac{\text { Rp. } 508.312 .000 .000}{\text { Rp. 6.663.631.000.000 }} \times \text { Rp. } 98.211 .000 .000 \\
& =\quad \text { Rp. 7.492.000.000 }
\end{aligned}
$$

2. Hitung "Bagi Hasil untuk Seluruh Nasabah Per Produk"

Bagi Hasil

Seluruh Nasabah

$=$ PAD Per Produk $\mathrm{x}$ Nisbah $/ 100$

Per Produk

$$
\begin{aligned}
& =\text { Rp. } 7.492 .000 .000 \times 11,74 / 100 \\
& =\text { Rp. } 880.000 .000
\end{aligned}
$$


3. Hitung "Equivalent Rate Setiap Produk"

Equivalent Rate

Setiap Produk =
Bagi hasil untuk seluruh Nasabah Per Produk

$=\quad \begin{aligned} & \text { Total Saldo rata-rata per prod } \\ & \text { Rp. } 880.000 .000\end{aligned}$
$=\quad \begin{aligned} & \text { Rp. } 508.312 .000 .000 \\ & \text { Rp. } 2,08 \%\end{aligned}$
R $100 \%$

4. Hitung "Bagi Hasil Per Nasabah DPK"

Perhitungan Bagi Hasil Per Nasabah DPK dilakukan dengan mengalikan jumlah dana setiap Nasabah DPK dengan eqivalent rate yang telah dihitung pada butir $\mathrm{c}$ diatas.

Bagi hasil yang diterima Bapak Amir atas Tabungan Mudharabah pada bulan Juni adalah:

Bagi Hasil = Saldo Rata-rata bapak Amir $\mathrm{x}$ Equivalent rate (\%)

Bapak Amir

$$
\begin{aligned}
& =\text { Rp. } 5.000 .000 \times(2,08 \% /(365 / 30) \\
& =\text { Rp. } 5.000 .000 \times 2,08 \%(12,1666666666) \\
& =\text { Rp. } 5.000 .000 \times 0,1709 \% \\
& =\text { Rp. } 8.545
\end{aligned}
$$

Jurnal Pada Saat Penerimaan Bagi Hasil Mudharabah untuk Pak Amir untuk Bulan Juni 2014 adalah:

Hak Pihak Ketiga Atas Bagi Hasil Rp. 8.545

Tabungan Mudharabah

Rp. 8.545

\section{Tabel 3}

Distribusi Bagi Hasil

Tanggal 30 September 2014

(Jutaan Rupiah)

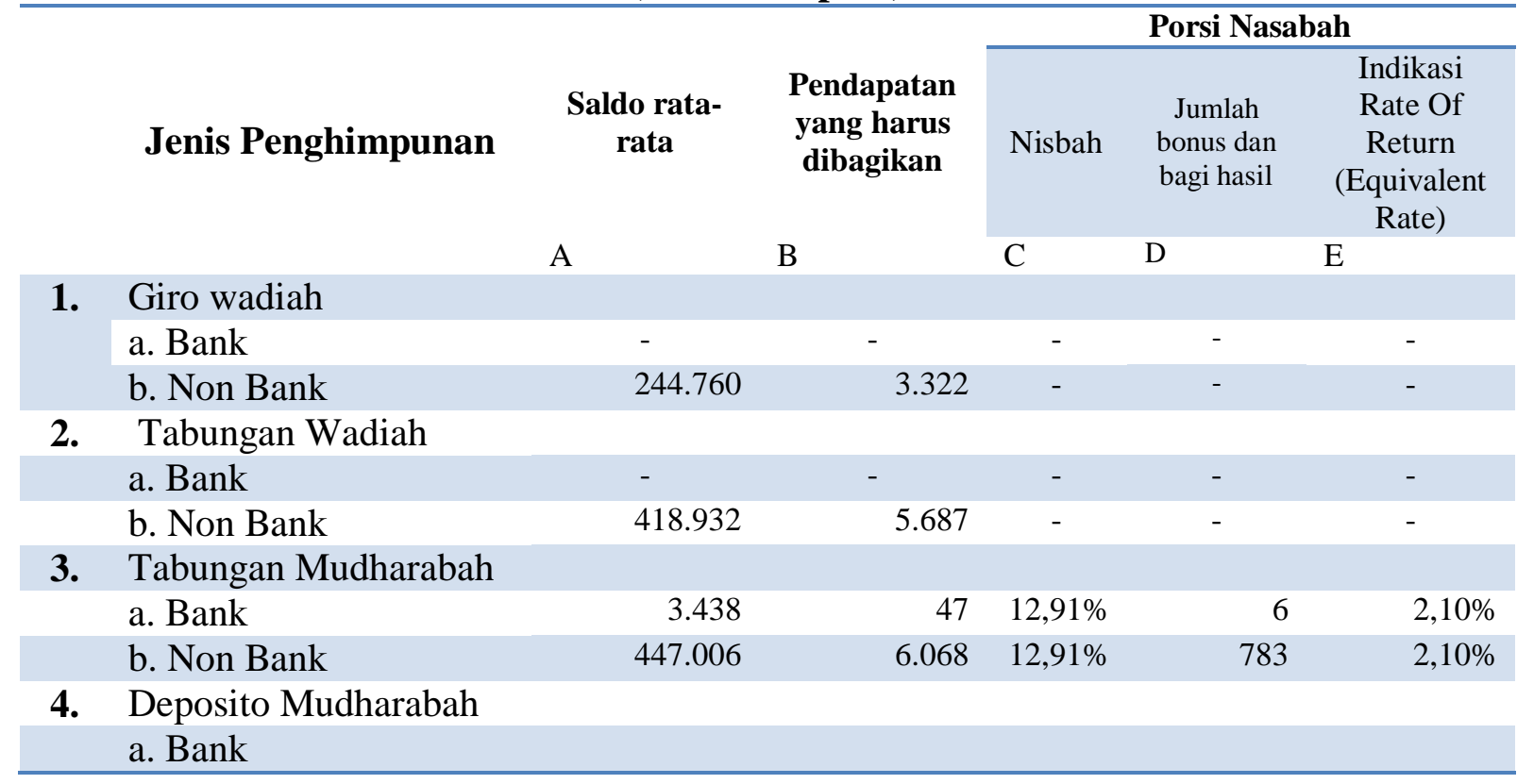




\begin{tabular}{lcrrrc}
\hline 1 bulan & 2.769 & 38 & $28,06 \%$ & 11 & $4,57 \%$ \\
3 bulan & - & - & - & - & - \\
6 bulan & - & - & - & - & - \\
12 bulan & - & - & - & - & - \\
\hline b. Non Bank & & & & & \\
1 bulan & 3.413 .702 & 46.338 & $28,06 \%$ & 13.002 & $4,57 \%$ \\
3 bulan & 1.499 .612 & 20.356 & $27,92 \%$ & 5.683 & $4,55 \%$ \\
\hline bulan & 170.089 & 2.309 & $26,68 \%$ & 616 & $4,35 \%$ \\
12 bulan & 82.456 & 1.119 & $26,68 \%$ & 299 & $4,35 \%$ \\
\hline Total & 6.282 .764 & 85.283 & - & 20.400 & - \\
\hline
\end{tabular}

Perhitungan bagi hasil untuk bapak amir pada bulan September 2014 adalah:

1. Hitung "PAD per produk"

Saldo rata-rata tiap jenis produk DPK

PAD per Produk $=$

Total Saldo rata-rata DPK

Rp. 447.066.000.000

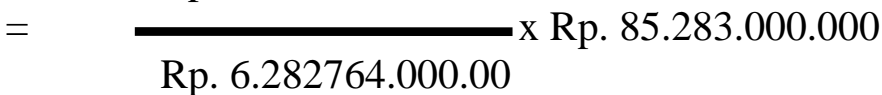

$=\quad$ Rp. 6.068.000.000

2. Hitung "Bagi Hasil untuk Seluruh Nasabah Per Produk"

Bagi Hasil

Seluruh Nasabah = PAD Per Produk x Nisbah $/ 100$

Per Produk

$$
\begin{aligned}
& =\text { Rp. } 6.068 .000 .000 \times 12,91 / 100 \\
& =\text { Rp. } 783.000 .000
\end{aligned}
$$

3. Hitung "Equivalent Rate Setiap Produk"

Equivalent Rate

Setiap Produk =
Bagi hasil untuk seluruh

$$
\text { Nasabah Per Produk }
$$

$$
\mathrm{x} 100 \%
$$

Total Saldo rata-rata per produk

Rp. 783.000.000

$$
\begin{aligned}
& =\quad \frac{\text { Rp. } 477 \cdot 066 \cdot 000 \cdot 000}{\text { Rp }} \times 100 \% \\
& =\quad \text { Rp. } 2,10 \%
\end{aligned}
$$

4. Hitung "Bagi Hasil Per Nasabah DPK"

Perhitungan Bagi Hasil Per Nasabah DPK dilakukan dengan mengalikan jumlah dana setiap Nasabah DPK dengan Equivalent rate yang telah dihitung pada butir $\mathrm{c}$ diatas.

Bagi hasil yang diterima Bapak Amir atas Tabungan Mudharabah pada bulan Juni adalah:

Bagi Hasil = Saldo Rata-rata bapak Amir x Equivalent rate (\%)

Bapak Amir

$$
\begin{aligned}
& =\text { Rp. } 5.000 .000 \times(2,10 \% /(365 / 30) \\
& =\text { Rp. } 5.000 .000 \times 2,10 \%(12,1666666666) \\
& =\text { Rp. } 5.000 .000 \times 0,1726 \% \\
& =\text { Rp. } 8.630
\end{aligned}
$$




\section{Jurnal Pada Saat Penerimaan Bagi Hasil Mudharabah untuk Pak Amir Hak Pihak Ketiga Atas Bagi Hasil Rp. 8.630 \\ Tabungan Mudharabah \\ Rp. 8.630}

Jadi dari contoh kasus yang di telusuri kebenaran bahwa Bank Mega syariah telah menerapkan perhitungan bagi hasil menggunakan metode Equivalent Rate. Dari data yang di uraikan bulan Maret, Juni dan September dapat disimpulkan bahwa bagi hasil yang diterapkan dengan menggunakan equivalent rate mengalami perubahan tiap bulannya yang mana bagi hasil ini lebih berpatokan pada besarnya pendapatan yang diperoleh setiap bulannya dapat dilihat pada grafik sebagai berikut:

\section{Gambar 1}

Grafik Kisaran Equivalent Rate Pak Amir

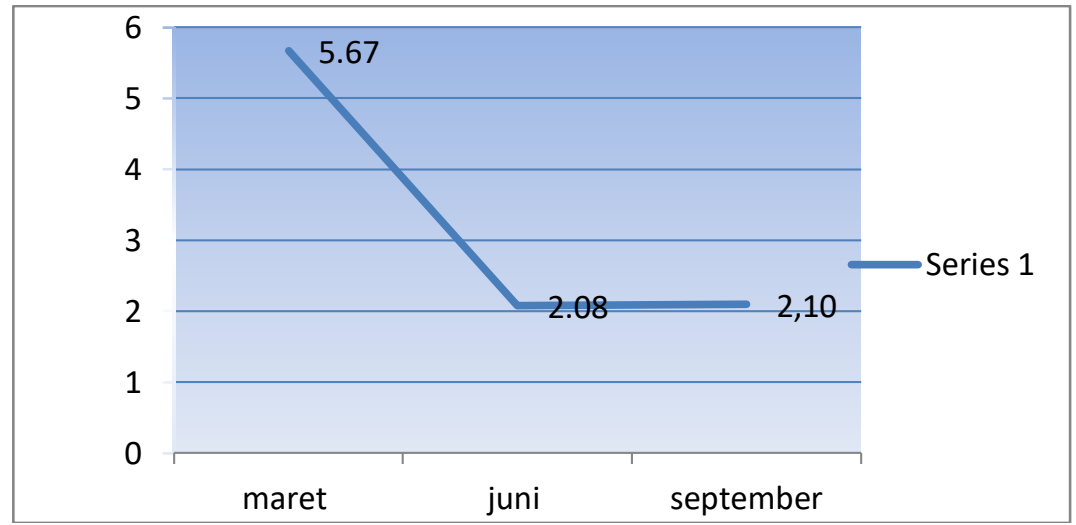

Grafik diatas menujukan perubahan terhadap kisaran equivalent rate yang mengalami fluktuatif (perubahan) setiap bulannya.

\section{Gambar 2}

Data Grafik Bagi hasil Pak Amir

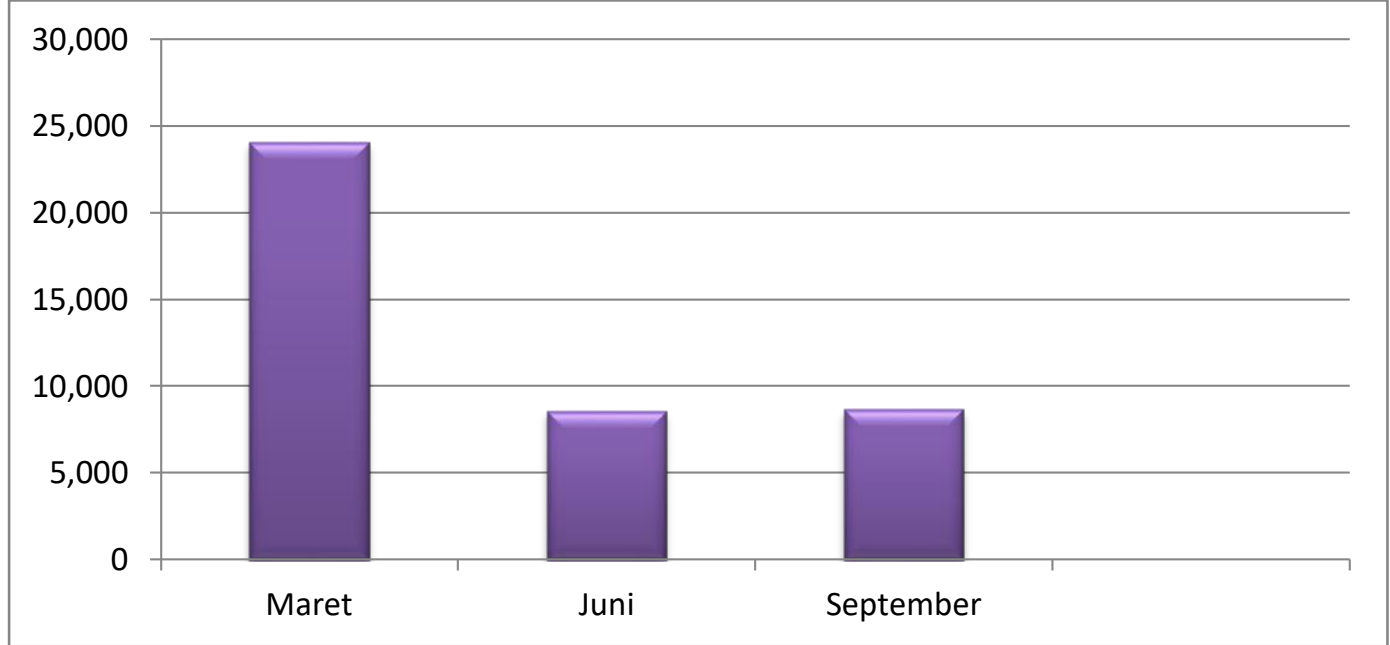

Grafik di atas menunjukan perubahan penerimaan bagi hasil pak amir dalam jumlah rupiah tiap bulannya. 


\section{Kesesuaian Perhitungan Bagi Hasil Tabungan Mudharabah dengan Fatwa MUI}

Salah satu transaksi berdasarkan prinsip syari'ah yang sering digunakan pada lembaga keuangan syari'ah adalah akad mudharabah mutlaqah seperti yang telah dipaparkan pada bab sebelumnya, mudharabah mutlaqah adalah tabungan mudarabah berdasarkan prinsip ini tidak ada pembatasan bagi bank dalam menggunakan dana yang di himpun. Tabungan yang tidak dibenarkan secara syari'ah yaitu tabungan berdasarkan perhitungan bunga.

PT. Bank Mega Syariah Kantor Cabang Pembantu Pekanbaru sudah menggunakan ketentuan Dewan Syariah Nasional Nomor 14/DSN-MUI/IX/2000 didalam Fatwa MUI tentang Sistem Distribusi Hasil Usaha Dalam Lembaga Keuangan Syariah menyatakan pada prinsipnya, Lembaga Keuangan Syariah boleh menggunakan sistem Accrual Basis maupun Cash Basis dalam administrasi keuangan. Dilihat dari segi kemaslahatan (al-ashlah), dalam pencatatan sebaiknya digunakan sistem Accrual Basis. Akan tetapi dalam distribusi hasil usaha hendaknya ditentukan atas dasar penerimaan yang benar-benar terjadi (Cash Basis).

Berdasarkan hasil penelitian, diperoleh bahwa bagi hasil yang di berikan kepada nasabah yang mana segala sesuatu yang dilakukan bank baik dalam mengeluarkan produk dan metode perhitungan bagi hasil pasti mengacu pada prinsip syariah yang sudah diatur oleh BI bersama DSN yang sesuai dengan Fatwa MUI salah satu metode yang digunakan ialah metode equivalent rate yang mana metode ini tidak menyimpang dan melanggar ketetapan sesuai syariah dari sistem distribusi bagi hasil yang di nyatakan pada Fatwa MUI. ${ }^{4}$

\section{Analisa Data.}

Berdasarkan penyajian data yang telah didapat, maka dapat penulis analisa, bahwa Bank Mega Syariah telah menggunakan perhitungan equivalent rate pada tabungan mudharabah (investasya iB) yang menggunakan akad mudharabah. Perhitungan equivalent rate yang dilaksanakan adalah dengan menggunakan Otomatis By Sistem.

Berdasarkan perhitungan secara manual yang telah penulis buat maka terbukti hasil equivalent rate yang dihitung menggunakan Otomatis By Sistem sama dengan hasil equivalent rate yang dihitung secara manual dengan menggunakan rumus. Dan perhitungan bagi hasil pada Bank Mega Syariah sudah menggunakan ketentuan Dewan Syariah Nasional Nomor 14/DSN-MUI/IX/2000 didalam Fatwa MUI tentang Sistem Distribusi Hasil Usaha Dalam Lembaga Keuangan Syariah.

\section{KESIMPULAN DAN SARAN}

Hasil penelitian yang telah peneliti lakukan, sehingga dapat disimpulkan sebagai berikut:

1. Bank Mega syariah telah menggunakan perhitungan equivalent rate pada tabungan mudharabah (investasya $i B$ ) yang menggunakan akad mudharabah. Perhitungan equivalent rate yang dilaksanakan adalah dengan menggunakan Otomatis By Sistem.

\footnotetext{
${ }^{4}$ Wawancara Karyawan BMS Cabang Pekanbaru, Ica, Bagian Coustemer Servis.
} 
2. Perhitungan secara manual yang telah penulis buat maka terbukti hasil equivalent rate yang dihitung menggunakan Otomatis By Sistem sama dengan hasil equivalent rate yang dihitung secara manual dengan menggunakan rumus. Dan perhitungan bagi hasil pada Bank Mega Syariah sudah menggunakan ketentuan Dewan Syariah Nasional Nomor 14/DSNMUI/IX/2000 didalam Fatwa MUI tentang Sistem Distribusi Hasil Usaha Dalam Lembaga Keuangan Syariah.

Adapun saran yang bisa peneliti berikan adalah sebagai berikut:

1. Diharapkan dengan adanya produk-produk pendanaan PT. Bank Mega Syariah Kantor Cabang Pembantu Pekanbaru dapat membantu masyarakat dalam memudahkan berinvestasi demi keamanan dan jaminan keuangan masyarakat serta dapat meningkatkan kesejahteran perekonomian masyarakat justru jangan sampai mempersulit nasabah untuk berinvestasi sehingga dapat meningkatkan pendapatan bagi Bank Mega Syariah KCP Pekanbaru.

2. Semoga diterapkannya perhitungan equivalent rate terhadap tabungan mudharabah akan meningkatkan lagi kepercayaan dan keinginan nasabah dalam menabung di karenakan memeiliki keadilan didalam pembagian bagi hasil. Serta mengacu pada prinsip-prinsip syariah mampu memberikan perhitungan bagi hasil secara transparan dan menjelaskan kepada nasabah sesuai ketentuan yang berlaku di perbankan syariah.

3. Melakukan inovasi terhadap tabungan mudharabah dengan menciptakan nilai tambah (keunggulan) tersendiri sehingga mampu bersaing dengan produk pada bank-bank lainnya.

4. Tabungan Mudharabah merupakan produk penghimpunan dana yang menguntungkan bagi pihak bank. Dimana pihak bank diberi kepercayaan penuh oleh nasabah untuk mengelola dana, oleh sebab itu sebaiknya pihak bank harus menberikan tingkat bagi hasil yang lebih tinggi agar nassabah mengajak keluarga, saudara, teman dan mitranya untuk menyimpan dananya.

\section{DAFTAR PUSTAKA}

Antonio, Muhammad Syafi'i. 2001. Bank Syari'ah dari Teori Ke Praktek. Cetakan 1. Jakarta: Gema Insani Press.

Ascarya. 2007. Akad dan Produk Bank Syariah. Jakarta: PT. Raja Grafindo Persada.

Dewan Syari'ah Nasional. 2000. Fatwa Dewan Syari'ah Nasional Nomor 02/DSN-MUI/IV/2000 Tentang Tabungan. Jakarta: DSN.

Dewan Syari'ah Nasional. 2000. Fatwa Dewan Syari'ah Nasional Nomor 14/DSN-MUI/IX/2000 Tentang Sistem Distribusi Hasil Usaha dalam LKS. Jakarta: DSN.

Dewan Syari'ah Nasional. Fatwa Dewan Syari'ah Nasional Nomor. 15/DSNMUI/IX/2000 Tentang Prinsip Bagi Hasil. Jakarta: DSN.

Dokumen Bank Mega Syariah Cabang Pekanbaru.

Ikatan Akuntan Indonesia. 2007. Pernyataan Standar Akuntansi Keuangan, Jakarta: Graha Akuntan.

Karim, Adiwarman A. 2004. Bank Islam Analisis Fiqih dan Keuangan, Edisi Empat. Jakarta: PT. Raja Grafindo Persada. 
Muhammad dan Suwiknyo, Dwi. 2009. Akuntansi Perbankan Syariah, Cetakan 1. Yogyakarta: TrustMedia.

Nurhayati, Sri dan Wasilah. 2009. Akuntansi Syariah Di Indonesia. Jakarta: Selemba Empat.

Redaksi Sinar Grafika. 2005. Undang-Undang Perbankan 1998 (Undang-Undang Nomor 10 Tahun 1998) cet. 5. Jakarta: Sinar Grafika.

Sumiyanto, Ahmad. 2005. Problem dan solusi transaksi Mudharabah, Cetakan 1. Yogyakarta: Magistra Insania Press.

Yahya, Akmal. Profit Distribution. http//www.ifibank.go.id. 